\title{
Ciri Morfologi Polen Dan Spora Tumbuhan Dari Sedimen Rawa Jombor Klaten
}

\author{
Solifa Sarah ${ }^{1}$, Sri Widodo Agung Suedy ${ }^{2}$, Endah Dwi Hastuti ${ }^{3}$ \\ Departemen Biologi, Fakultas Sains dan Matematika, Universitas Diponegoro. \\ Jl. Prof. H. Soedharto, SH, Tembalang, Semarang, Jawa Tengah, Indonesia 50275. \\ 1) email: solifa.sarah@yahoo.com \\ 2)email: agung.suedy@gmail.com. \\ 3) email: Endah.pdil@yahoo.com
}

\begin{abstract}
The Marsh of Jombor Klaten is a natural swamp that was once small swamps surrounded by villages and hills located in the lower mainland and serves to hold rainwater. Environmental has changed from the lowlands into the aquatic environmentand the more widespread the diversity of types of flora around the Swamp Jombor has been changed.The diversity of types of flora can be known through the morphology of the pollen and spores. The purpose of this research is to know the diversity of plant species based on morphology of pollen and spores found in Swamp sediment Jombor. Sampling is done by drilling sedimentary soil clays Swamp Jombor on three points with the first location code RWJ (3) at a depth of $2 \mathrm{~m}$ situated around the keramba, the second code RWJ (4) at a depth of $1.5 \mathrm{~m}$, and third code RWJ (5) at a depth of $0.35 \mathrm{~m}$ located around the inlet. The sample preparation using method asetolisis, then morphological characteristics observed pollen and spores. Calculated the number of each type of pollen and spores. The data obtained were analyzed using pollen and spore morphology of description. The data obtained were analyzed using pollen morphology characteristics and description of the spores found in the swamp Jombor. The results showed that the morphology of the pollen and spores found in Swamp sediment Jombor has a variation of shapes and sizes. The flora type obtained from the sediments Swamp Jombor as much as 28 type, including 8 typearboreal pollen (AP), 9 typenon arboreal pollen (NAP), and 11 type of spores. Types of flora that dominates is the NAP family Gramineae $(80,10 \%)$ which indicates the plant a tree instead of in the form of shrubs or herbaceous were more developed in marsh of Jomborenvironment.
\end{abstract}

Keywords: Jombor, morphology, pollen, spore, diversity.

\begin{abstract}
Abstrak
Rawa Jombor Klaten merupakan Rawa alami yang dulunya adalah rawa kecil yang dikelilingi oleh perkampungan dan perbukitan yang terletak di daratan dataran rendah dan berfungsi untuk menampung air hujan. Perubahan lingkungan dari daratan kemudian menjadi lingkungan perairan dan semakin meluas tersebut menyebabkan keanekaragaman jenis flora disekitar Rawa Jombor telah berubah. Keanekaragaman jenis flora dapat diketahui melalui morfologi polen dan spora. Tujuan dari penelitian ini adalah untuk mengetahui keanekaragaman jenis tumbuhan berdasarkan morfologi polen dan spora yang ditemukan dalam sedimen Rawa Jombor. Pengambilan sampel dilakukan dengan pengeboran sedimen tanah lempung Rawa Jombor pada tiga titik lokasi yang pertama dengan kode RWJ(3) pada kedalaman $2 \mathrm{~m}$ terletak disekitar keramba, yang kedua kode RWJ(4) pada kedalaman 1.5 $\mathrm{m}$, dan ketiga kode RWJ(5) pada kedalaman 0,35 m terletak disekitar inlet. Sampel tanah tersebut dipreparasi dengan metode asetolisis kemudian diamati ciri dan sifat morfologi polen dan spora. Selanjutnya dihitung jumlah masingmasing tipe polen dan spora.Data yang diperoleh dianalisis menggunakan deskripsi morfologi polen dan spora. Data yang diperoleh dianalisis menggunakan deskripsi ciri morfologi polen dan spora yang ditemukan di Rawa Jombor. Hasil penelitian menunjukkan bahwa morfologi polen dan spora yang ditemukan dalam sedimen Rawa Jombor memiliki variasi bentuk dan ukuran.Tipe flora yang diperoleh dari sedimen Rawa Jombor sebanyak 28tipe diantaranya 8 tipearborealpollen, 9 tipenonarborealpollen, dan 11 tipe spora. Tipe flora yang mendominasi adalah dari kelompok NAP famili Gramineae $(80,10 \%)$ yang menandakan tanaman bukan pohon berupa semak atau herba lebih berkembang di lingkungan sekitar Rawa Jombor.
\end{abstract}

Kata kunci: Rawa Jombor, morfologi, polen, spora, keanekaragaman. 


\section{PENDAHULUAN}

Rawa Jombor merupakan salah satu rawa alami yang ada di Indonesia. Rawa Jombor awalnya berupa rawa kecil yang berfungsi untuk menampung air hujan. Seiring waktu rawa ini meluas dan pemukiman disekitarnya mulai terendam hingga penduduk pindah ke daerah yang lebih tinggi. Rawa Jombor terletak di desa Krakitan, Kecamatan Bayat yang termasuk pegunungan kapur. Rawa ini merupakan rawa yang sangat luas di Kabupaten Klaten, jaraknya \pm 8 km kearah tenggara dari Kota Klaten. Rawa Jombor memiliki peranan penting bagi penduduk sejak tahun 1967 untuk irigasi pertanian, tahun 1986 untuk lahan budidaya ikan, dan pada tahun 1998 mulai dibangun usaha warung apung untuk mendukung tempat wisata di rawa tersebut.

Danau atau rawa merupakan salah satu tempat yang baik untuk menyimpan hasil-hasil sedimentasi yang kemudian dapat menjadi sebuah bukti palinologi untuk mengetahui perubahan vegetasi disekitar Rawa Jombor. Menurut Moore and Webb (1978) and Morley (1990) palinologi adalah ilmu yang mempelajari polen (serbuk sari) tumbuhan tinggi dan spora tumbuhan rendah. Dalam palinologi juga dipelajari mengenai struktur, bentuk maupun preservasinya di bawah kondisi tertentu. Keterdapatan dan distribusi butiran polen pada suatu sedimen dapat digunakan untuk merekonstruksi lingkungan darat dan transisi, hal ini tidak terlepas dari kondisi lingkungan yang mampu mengawetkan polen tersebut. Salah satu media pengawetannya adalah endapan yang terbentuk di daerah rawa atau danau.Sejak terbentuknya Rawa Jombor hingga saat ini, flora penyusun vegetasi di Rawa Jombor dapat diketahui melalui polen dan spora yang terendapkan dalam sedimen Rawa Jombor.

Polen merupakan gametofit jantan pada tumbuhan Gymnospermae dan Angiospermae, sedang spora biasanya dihasilkan oleh tumbuhan non vaskuler seperti alga, jamur, lumut serta tumbuhan vaskuler tingkat rendah yaitu pakupakuan (Agashe and Caulton, 2009).Polen dan spora yang terendapkan di dalam setiap lapisan sedimen Rawa Jombor dapat digunakan sebagai sumber data palinologi untuk melihat dan menghitung jenis atau tipe polen dan spora yang hadir, keanekaragaman dan kesamaan polen dan spora, serta untuk melihat perubahan lingkungan dan iklim masa lampau di rawa tersebut. Polen dan spora yang ditemukan diidentifikasi morfologinya sehingga dapat diketahui takson flora penghasilnya, habitus, dan habitat dari tumbuhan penghasilnya.

Penelitian palinologi di Indonesia antara lain penelitian mengenai fosil polen yang digunakan untuk mengetahui sejarah flora dan vegetasi daerah Bumiayu kala Pliosen oleh Setijadi dkk (2005).Penelitian palinologi lainnya mengenai perubahan lingkungan masa Holoscene daerah Rawa Danau-Jawa Barat (Yulianto, et al., 2005); keanekaragaman flora hutan mangrove pantai utara Jawa Tengah (Suedy, dkk. 2006a; Suedy, dkk. 2006b;Suedy, dkk. 2007). Sedangkan untuk penelitian di luar negeri telah dilakukan oleh Behling dan Pillar (2007), dengan menggunakan bukti palinologi untuk merekonstruksi dinamika vegetasi dan biodiversitas dibagian selatan Brazilia pada kala Kuarter akhir. Penelitian oleh Ellison (2008) untuk memprediksi dinamika vegetasi, perubahan muka air laut serta perubahan iklim pada daerah pesisir.

Kondisi Rawa Jombor saat ini sedang mengalami permasalahan lingkungan dengan terjadinya pendangkalan yang tinggi dimana pada musim penghujan disekitar Rawa Jombor mengalami banjir sedangkan pada musim kemarau mengalami kekeringan, serta permasalahan sampah disekitar Rawa Jombor yang belum terselesaikan. Oleh sebab itu diperlukan penelitian seperti identifikasi vegetasi melalui studi palinologi untuk mengetahui keanekaragaman flora yang tumbuh di sekitar Rawa Jombor pada masa lampau. Keanekaragaman jenis tumbuhan yang tumbuh disekitar Rawa Jombor dapat ditentukan oleh ciri polen dan spora melalui identifikasi morfologi polen dan spora yang ditemukan di rawa tersebut, sehingga dapat diketahui habitus dan tumbuhan penghasilnya. Dari data yang diperoleh dari penelitian ini diharapkan dapat dijadikan sebagai acuan dalam merekonstruksi perubahan kondisi lingkungan dimasa lampau karena tumbuhan mempunyai kepekaan terhadap perubahan kondisi lingkungan dan untuk mendukung penelitian 
lanjutan dalam upaya konservasi lingkungan Rawa Jombor. Menurut Raharjo dkk (1998) data palinologi dapat menjadi acuan untuk mengetahui perubahan iklim masa lampau dan dapat dijadikan sebagai dasar dalam merekonstruksi vegetasi lingkungan, iklim, sejarah flora, upaya konservasi dan pencegahan bencana alam.

\section{BAHAN DAN METODE Tempat dan Waktu Penelitian}

Penelitian ini terdiri dari dua tahap yakni penelitian lapangan dan penelitian laboratorium. Penelitian lapangan meliputi pengambilan sampel sedimen Rawa Jombor di tiga titik lokasi yaitu disekitar keramba, dan yang keduanya disekitar inlet. Penelitian laboratorium meliputi preparasi sampel sedimen Rawa Jombor yang kemudian dibuat preparat mikroskopis yang dilakukan di Laboratorium Palinologi Paleobotani, Prodi Teknik Geologi Universitas Jenderal Soedirman Purwokerto, dan pengamatan, identifikasi serta analisis data dilakukan di Laboratorium Biologi Dasar, jurusan Biologi Fakultas Sains dan Matematika Universitas Diponegoro Semarang. Penelitian dilaksanakan pada Januari 2015-Januari 2016.

\section{Bahan dan Alat}

Bahan - bahan yang digunakan dalampenelitian ini diantaranya sampel sedimen, aquadest, $\mathrm{HNO}_{3}, \mathrm{KOH} 5 \%, \mathrm{HCl} 33 \%$, $\mathrm{HF} 40 \%$, alkohol $10 \%$, gliserin jelly, entelan, kertas lakmus biru. Alat-alat yang digunakan yaitu kertas label, alat tulis, kamera, alat bor, paralon, plastic wrap, cutter, timbangan analitik, masker, sarung tangan, gelas beker, gelas ukur, mortar dan penumbuk, pengaduk kayu, botol flakon, tabung reaksi dan rak tabung, baki, kompor listrik, saringan nilon, corong, pinset, lemari asam, filter aquadest, mikropipet, yellow tip, tusuk gigi, hot plate, kaca preparat dan kaca penutup, cutton bud, dan mikroskop.

\section{Cara kerja}

Pengambilan sampel

Pengambilan sampel sedimen dilakukan di tiga titik lokasi yang pertama yaitu sampel sedimen ketiga dengan kode RWJ(3) diambil dari sekitar keramba dengan titik koordinat 07² '17,9'"LS ; 110 37'44,6'BT pada kedalaman $2 \mathrm{~m}$. Sedangkan titik lokasi yang kedua di sekitar inlet dua yaitu sampel sedimen keempat dengan kode RWJ(4) dan kelima dengan kode RWJ(5) dimana titik koordinat sampel keempat $07^{\circ} 45^{\prime} 12,3^{\prime \prime} \mathrm{LS} \quad ; \quad 10^{\circ} 37^{\prime} 44,5^{\prime \prime}$ 'BT dan sampel kelima07'45'12.3'LS : 10³7'44,5'BT. Sampel sedimen keempat diambil pada kedalaman $1,5 \mathrm{~m}$, dan sampel kelima pada kedalaman 0,35 $\mathrm{m}$. Sampel sedimen diambil dengan cara mengebor titik lokasi setiap sampel diatas menggunakan alat bor berdiameter $1 \mathrm{dim}( \pm 4 \mathrm{~cm})$ dengan kedalaman masing-masing sampel yang telah disebutkan diatas. Pengambilan sampel yang terletak di sekitar keramba dan inlet ini untuk melihat sejauh mana perbedaan komposisi penyusun vegetasi dari sedimen yang berada di inlet yang merupakan saluran masuknya air dari sekitar Rawa Jombor dengan sedimen sekitar keramba yang lokasinya lebih mengarah ke tengah perairan Rawa Jombor. sampel sedimen yang telah diambil diberi kode RWJ(3/4/5), kemudian diberi tanda lapisan paling atas sebagai lapisan berumur tua dan lapisan paling bawah adalah lapisan berumur muda.

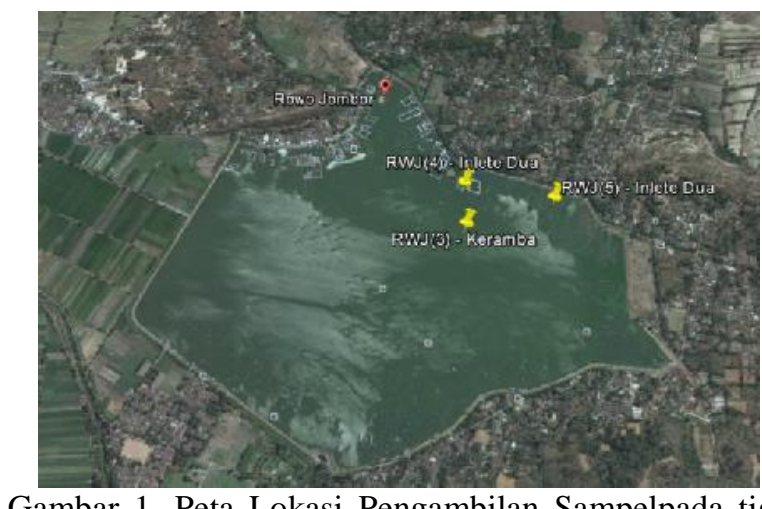

Gambar 1. Peta Lokasi Pengambilan Sampelpada tiga titik lokasi

Preparasi Sampel Sedimen dan Pembuatan Preparat

Preparasi polen dan spora menggunakan metode moore and webb (1978) yang telah dimodifikasi oleh Suedy dan Setijadi (2009):

a. Sampel sedimen 5 gr dalam gelas bekker diberi larutan $\mathrm{HCl} 33 \%$, diamkan selama 3 jam, dan netralkan dengan akuades sebanyak 4-5 kali. 
b. Sampel sedimen diberi larutan HF 40\%, diamkan selama 24 jam dan netralkan dengan akuades sebanyak 4-6 kali.

c. Sampel sedimen diberi larutan $\mathrm{HCl} 33 \%$, panaskan selama 2 jam dan netralkan dengan akuades sebanyak 4-5 kali.

d. Sampel disaring menggunakan saringan bertingkat $10 \mu \mathrm{m}$ dan $5 \mu \mathrm{m}$. Sampel diberi larutan HNO3 dan panaskan selama 10 menit. Sampel dinetralkan dengan akuades dan saring dengan saringan ukuran $5 \mu \mathrm{m}$.

e. Sampel diberi larutan $\mathrm{KOH} 5 \%$ dan panaskan selama 5 menit. Netralkan sampel dengan akuades dan masukkan kedalam botol vial.

f. Sampel sebanyak $200 \mu$ l teteskan pada kaca benda, keringkan diatas hotplate, tetesi dengan entelan dan tutup dengan kaca penutup.

\section{Identifikasi Polen dan Spora}

Identifikasi polen dan spora dilakukan dengan pengamatan dibawah mikroskop pada perbesaran 400x-1000x untuk melihatciri morfologi berupa bentuk, ukuran,tipe polaritas, simetri,tipeapertur, serta ornamentasi eksin. Jumlah individu setiap sampel yang diamati minimal berkisar 100 individu. Identifikasi polen dan spora ini menggunakan beberapa refrensi diantaranya: Erdtman (1952), Huang (1972), Morley (1990), Hesse (2009), Kapp (1969), Moore and Webb (1978), dan Traverse (1988).

\section{Analisis data}

Analisis polen dan spora yang ditemukan pada sedimen Rawa Jombor dilakukan melalui deskripsi morfologi polen dan spora yang meliputi ukuran, indeks $\mathrm{P} / \mathrm{E}$ yaitu perbandingan diameter polar dan ekuatorial (P/E),tipe aperture, simetri,polaritas dan ornamentasi eksin.Polen dan spora yang telah teridentifikasi kemudian dikelompokkan berdasarkan habitusnya yaituArborealpollen (AP) yang merupakan polen yang berasal dari tumbuhan pohon, NonArborealPollen (NAP) merupakan polen yang berasal dari tumbuhan semak atau herba, dan kelompok Pteridophyta.

\section{HASIL DAN PEMBAHASAN}

Berdasarkan hasil pengamatan dengan mikroskop dari perbesaran 400x hingga 1000x maka diperoleh polen dan spora dengan berbagai bentuk dan ukuran yang bervariasi. Setelah polen dan spora diamati kemudian diperoleh data hasil identifikasi dengan merujuk dari berbagai referensi buku. Hasil dari identifikasi akan diketahui tumbuhan penghasil polen dan spora tersebut. Hasil identifikasi dari polen dan spora yang berhasil di identifikasi pada tingkat famili sebanyak 11 tipe diantaranya Bignoniaceae, Bombacaceae, Myrtaceaea, Ulmaceae, Asteraceae, Euphorbiaceae, Gramineae, Malvaceae, Marantaceae, Davaliaceae dan Polypodiaceae. Polen dan spora yang teridentifikasi hingga tingkat genus sebanyak 10 tipe diantaranya Pinus sp., Celtis sp., Croton sp., Polygonum sp., Gleichenia sp., Lycopodium sp., Psilotum sp., Pteris sp., dan Selaginella sp., polen dan spora yang teridentifikasi hingga tingkat spesies sebanyak 7 tipe diantaranya Acacia acutiformis, Podocarpus polystachyus, Celtis alba, Actinostachys digitata, Ceratopteris thalictroides, Lygodium scandens dan Stenochlaena palustris.

Ciri morfologi polen dan spora yang ditemukan dalam sedimen Rawa Jombor Klaten adalah sebagai berikut: 
Tabel 1. Morfologi polen dan spora yang ditemukan pada sedimen Rawa Jombor Klaten

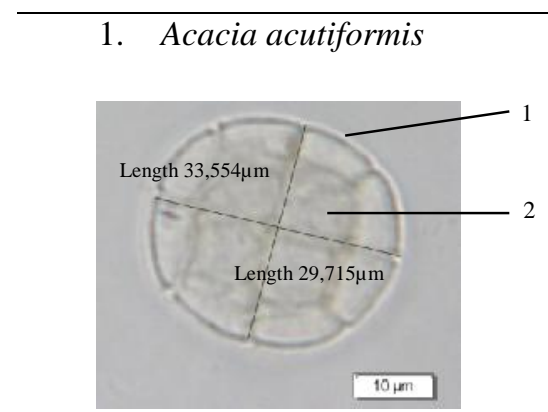

1. Butir polen 2. Eksin

4. Croton sp.

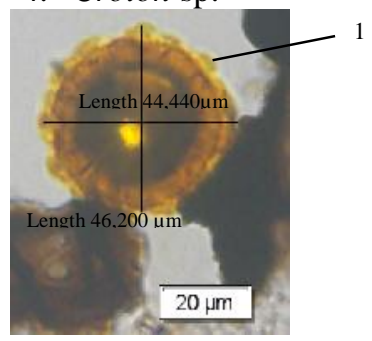

1. Eksin

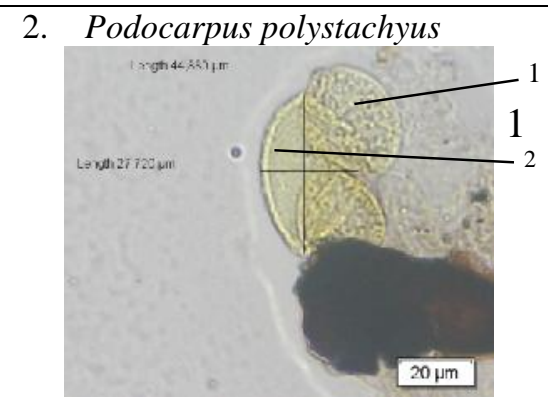

1. Saccus 2. Eksin

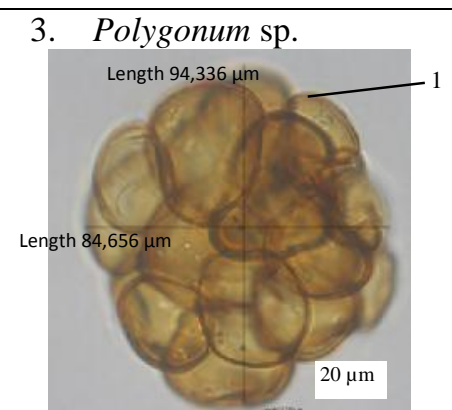

1. Eksin
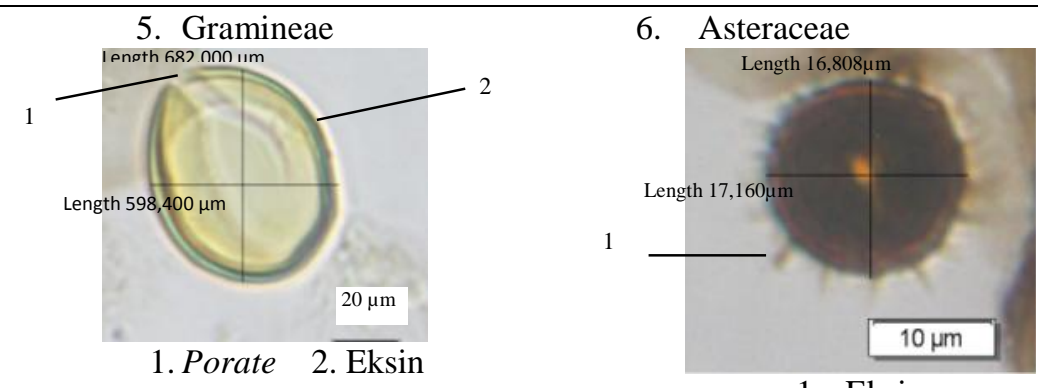

1. Eksin

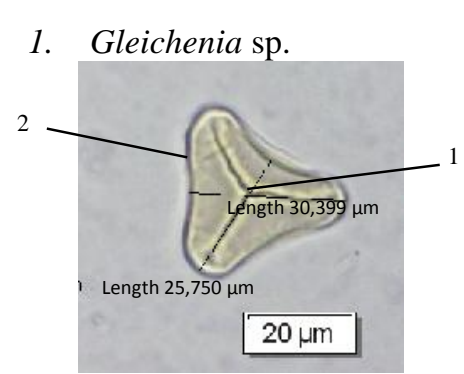

1. Trilete 2. Eksin

2. Actinostachys digitata Length $33,528 \mu \mathrm{m}$

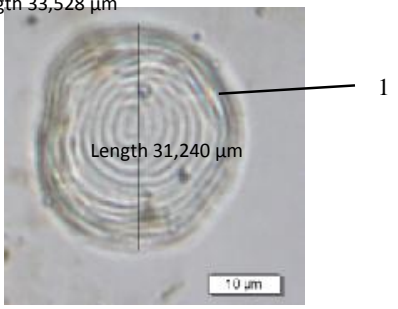

1. Eksin
3. $\quad$ Pteris sp.

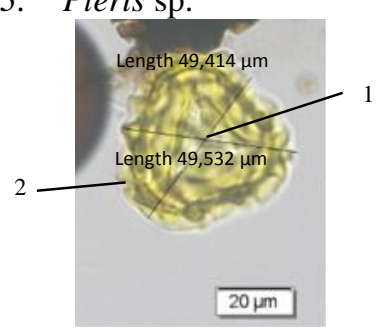

Tabel 2. Karakteristik ciri morfologi polen dan spora yang ditemukan pada sedimen Rawa Jombor Klaten Purwodadi

\begin{tabular}{|c|c|c|c|c|c|c|c|c|c|}
\hline \multirow{2}{*}{ No } & \multirow{2}{*}{ Jenis } & \multicolumn{2}{|c|}{ Ukuran } & \multirow{2}{*}{$\begin{array}{l}\text { Indeks } \\
\mathrm{P} / \mathrm{E}\end{array}$} & \multirow{2}{*}{ Bentuk } & \multirow{2}{*}{ Simetri } & \multirow{2}{*}{ Apertura } & \multirow{2}{*}{ Polaritas } & \multirow{2}{*}{ Ornamentas } \\
\hline & & Panjang (P) & Lebar (L) & & & & & & \\
\hline 1 & $\begin{array}{l}\text { Acacia } \\
\text { acutiformis }\end{array}$ & $33,554 \mu \mathrm{m}$ & $29,715 \mu \mathrm{m}$ & 1,13 & $\begin{array}{l}\text { Prolate } \\
\text { spheroidal }\end{array}$ & Bilateral & Tricolporate & Heteropolar & Psilate \\
\hline 2 & $\begin{array}{l}\text { Podocarpus } \\
\text { polystachyus }\end{array}$ & $44,88 \mu \mathrm{m}$ & $27,72 \mu \mathrm{m}$ & 1,62 & Prolate & Bilateral & Bissacate & Heteropolar & Reticulate \\
\hline 3 & $\begin{array}{l}\text { Polygonum } \\
\text { sp. }\end{array}$ & $99,336 \mu \mathrm{m}$ & $84,656 \mu \mathrm{m}$ & 1,11 & $\begin{array}{l}\text { Prolate } \\
\text { spheroidal }\end{array}$ & Bilateral & Tricolporate & Heteropolar & Scabrate \\
\hline 4 & Crotonsp. & $46,200 \mu \mathrm{m}$ & $44,440 \mu \mathrm{m}$ & 1,03 & $\begin{array}{l}\text { Prolate } \\
\text { spheroidal }\end{array}$ & Radial & Inaperture & Isopolar & Crotonoid \\
\hline 5 & Gramineae & $682,000 \mu \mathrm{m}$ & $598,400 \mu \mathrm{m}$ & 1,14 & $\begin{array}{l}\text { Prolate } \\
\text { spheroidal }\end{array}$ & Bilateral & Porate & Heteropolar & Psilate \\
\hline
\end{tabular}




\begin{tabular}{|c|c|c|c|c|c|c|c|c|c|}
\hline 6 & Asteraceae & $17,160 \mu \mathrm{m}$ & $16,808 \mu \mathrm{m}$ & 1,02 & $\begin{array}{l}\text { Prolate } \\
\text { spheroidal }\end{array}$ & Radial & Porate & Isopolar & Echinate \\
\hline 7 & Gleichenia sp. & $30,399 \mu \mathrm{m}$ & $25,750 \mu \mathrm{m}$ & 1,18 & Subprolate & Bilateral & Trilete & Heteropolar & Fossulate \\
\hline 8 & $\begin{array}{l}\text { Actinostachys } \\
\text { digitata }\end{array}$ & $33,528 \mu \mathrm{m}$ & $31,240 \mu \mathrm{m}$ & 1,05 & $\begin{array}{l}\text { Prolate } \\
\text { spheroidal }\end{array}$ & Bilateral & Monolete & Heteropolar & Striate \\
\hline 9 & Pteris sp. & $49,532 \mu \mathrm{m}$ & $49,414 \mu \mathrm{m}$ & 1,00 & $\begin{array}{l}\text { Oblate } \\
\text { spheroidal }\end{array}$ & Radial & Trilete & Isopolar & Verrucate \\
\hline 10 & Bignoniaceae & $\begin{array}{c}1632,400 \\
\mu \mathrm{m}\end{array}$ & $\begin{array}{c}1331,000 \\
\mu \mathrm{m}\end{array}$ & 0,81 & Suboblate & Bilateral & Inaperture & Heteropolar & Foveolate \\
\hline 11 & Bombaceae & $\begin{array}{c}737,838 \\
\mu \mathrm{m}\end{array}$ & $\begin{array}{c}732,568 \\
\mu \mathrm{m}\end{array}$ & 1,00 & $\begin{array}{l}\text { Oblate } \\
\text { spheroidal }\end{array}$ & Bilateral & Inaperture & Heteropolar & Baculate \\
\hline 12 & Myrtaceae & $33,449 \mu \mathrm{m}$ & $29,094 \mu \mathrm{m}$ & 1,14 & Perprolate & Bilateral & Syncolporate & Heteropolar & Verrucate \\
\hline 13 & Pinus sp. & $58,368 \mu \mathrm{m}$ & $51,437 \mu \mathrm{m}$ & 1,13 & $\begin{array}{l}\text { Prolate } \\
\text { spheroidal }\end{array}$ & Bilateral & Bisaccate & Heteropolar & Reticulate \\
\hline 14 & Ulmaceae & $54,365 \mu \mathrm{m}$ & $46,389 \mu \mathrm{m}$ & 1,17 & Subprolate & Bilateral & Periporate & Heteropolar & Verrucate \\
\hline 15 & Celtis alba & $17,776 \mu \mathrm{m}$ & $17,248 \mu \mathrm{m}$ & 1,03 & $\begin{array}{l}\text { Prolate } \\
\text { spheroidal }\end{array}$ & Radial & Triporate & Isopolar & Scabrate \\
\hline 16 & Celtis sp. & $24,640 \mu \mathrm{m}$ & $23,100 \mu \mathrm{m}$ & 1,06 & Prolate & Radial & Triporate & Isopolar & Scabrate \\
\hline 17 & Euphorbiaceae & $48,190 \mu \mathrm{m}$ & $36,718 \mu \mathrm{m}$ & 1,31 & Subprolate & Bilateral & Tricolpate & Heteropolar & Foveolate \\
\hline 18 & Malvaceae & $48,400 \mu \mathrm{m}$ & $45,056 \mu \mathrm{m}$ & 1,07 & $\begin{array}{l}\text { Prolate } \\
\text { spheroidal }\end{array}$ & Bilateral & Periporate & Heteropolar & Echinate \\
\hline 19 & Marantaceae & $33,528 \mu \mathrm{m}$ & $31,856 \mu \mathrm{m}$ & 1,05 & $\begin{array}{l}\text { Prolate } \\
\text { spheroidal }\end{array}$ & Bilateral & Monoporate & Heteropolar & Psilate \\
\hline 20 & $\begin{array}{l}\text { Ceratopteris } \\
\text { thalictroides }\end{array}$ & $\begin{array}{c}116,223 \\
\mu \mathrm{m}\end{array}$ & $96,560 \mu \mathrm{m}$ & 1,20 & Subprolate & Bilateral & Trilete & Anisopolar & Striate \\
\hline 21 & Davalliaceae & $48,284 \mu \mathrm{m}$ & $32,686 \mu \mathrm{m}$ & 1,47 & Prolate & Bilateral & Monolete & Heteropolar & Reticulate \\
\hline 22 & Lycopodium sp. & $51,048 \mu \mathrm{m}$ & $45,868 \mu \mathrm{m}$ & 1,25 & Subprolate & Bilateral & Trilete & Heteropolar & Reticulate \\
\hline 23 & $\begin{array}{l}\text { Lygodium } \\
\text { scandens }\end{array}$ & $12,02 \mu \mathrm{m}$ & $11,28 \mu \mathrm{m}$ & 1,11 & $\begin{array}{l}\text { Prolate } \\
\text { spheroidal }\end{array}$ & Bilateral & Trilete & Heteropolar & Baculate \\
\hline 24 & Polypodiaceae & $54,679 \mu \mathrm{m}$ & $34,522 \mu \mathrm{m}$ & 1,58 & Prolate & Bilateral & Monolete & Heteropolar & Psilate \\
\hline 25 & Selaginella sp. & $45,245 \mu \mathrm{m}$ & $45,328 \mu \mathrm{m}$ & 1,00 & $\begin{array}{l}\text { Oblate } \\
\text { spheroidal }\end{array}$ & Radial & Trilete & Isopolar & Echinate \\
\hline 26 & Psilotum sp. & $911,475 \mu \mathrm{m}$ & $584,497 \mu \mathrm{m}$ & 1,55 & Prolate & Bilateral & Monolete & Heteropolar & Psilate \\
\hline 27 & $\begin{array}{l}\text { Stenochlaena } \\
\text { palustris }\end{array}$ & $95,049 \mu \mathrm{m}$ & $53,402 \mu \mathrm{m}$ & 1,77 & Prolate & Bilateral & Monolete & Heteropolar & Verrucate \\
\hline
\end{tabular}

Polen dan spora yang telah diidentifikasi selanjutnya dikelompokkan berdasarkan habitusnya yaitu ArborealPollen (AP) dan NonArborealPollen (NAP) sedangan spora dikelompokkan tersendiri. Menurut Prebble et al. (2005) AP tersusun oleh polen dari tumbuhan berkayu berupa pohon penyusun vegetasi hutan, sedangkan NAP tersusun oleh polen dari tumbuhan non berkayu yang terdiridari semak dan herba. Tipe polen dan spora yang ditemukan dalam sedimen Rawa Jombor sebanyak 27 tipe terdiri dari 7 tipe ArborealPollen (AP), 9 tipe NonArborealPollen (NAP), dan 11 tipe Spora (Pteridophyta). Tipe yang ditemukan didominasi oleh kelompok NAP darifamili Gramineae.
Secara keseluruhan tipe flora yang ditemukan pada sedimen Rawa Jombor didominasi oleh kelompok NonArborealPollen (NAP) atau kelompok tumbuhan semak atau herba. Hal ini dikarenakan tumbuhan semak atau herba lebih mudah tumbuh pada kondisi lingkungan di Rawa Jombor yaitu lingkungan yang terbuka dengan intensitas cahaya yang cukup dan tidak terhalang oleh tajuk pohon dan dekat dengan aliran sungai. Sesuai dengan pendapat Gusmaylina (1983) bahwa umumnya tanaman semak atau herba merupakan tanaman pionir dan keanekaragaman jenis semak dan herba sangat dipengaruhi oleh faktor lingkungan seperti cahaya, kelembaban, dan tutupan tajuk dari pohon sekitarnya. Taksa flora 
kelompok NAP yang menandakan lingkungan dan iklim yang dingin dan kering yang didominasi oleh famili Gramineae. Gramineae merupakan tumbuhan kelompok rumput-rumputan yang hidup dengan baik pada iklim kering (Rahardjo 1999 and Morley 1998; Morley et al. 2000 and Lelono et al. 2001).

\section{KESIMPULAN}

Morfologi polen dan spora yang ditemukan pada sedimen Rawa Jombor Klaten memiliki bentuk, ukuran, polaritas, simetri, apertur, dan ornamentasi eksin yang bervariasi. Jenis polen dan spora yang ditemukan dari keseluruhan sampel sedimen sebanyak 27 tipe, yang teridentifikasi pada tingkat famili sebanyak 11 tipe, tingkat genus sebanyak 9 tipe, tingkat spesies sebanyak 7 tipe.Jenis polen dan spora yang ditemukan pada keseluruhan sampel sedimen Rawa Jombor berdasarkan habitusnya terdiri dari Arboreal Pollen (AP) sebanyak 7 tipe, Non Arboreal Pollen (NAP) sebanyak 9 tipe, dan Spora (Pteridophyta) sebanyak 11 tipe. Berdasatkan persentase kehadiran polen dan spora yang ditemukan jenis flora yang mendominasi sedimen Rawa Jombor dari kelompok NAP yaitu dari famili Gramineae.

\section{UCAPAN TERIMAKASIH}

Penulis ingin mengucapkan rasa terima kasih yang sebesar-besarnya kepada Drs. Rachmad Setijadi, M.Si selaku dosen Teknik Geologi Universitas Jenderal Soedirman yang telah memberikan izin penelitian, bimbingan, pengarahan, kritik, saran dan doa serta nasihatnya selama proses penelitian di Laboratorium Teknik Geologi Universitas Jenderal Soedirman, serta kepada Dr. Sri Widodo Agung Suedy, M.Si dan Dr. Endah Dwi Hastuti, M.Sisebagai dosen pembimbing penelitian yang telah memberikan bimbingan, pengarahan, kritik, saran, motivasi dan doa selama penelitian.

\section{DAFTAR PUSTAKA}

Agashe, S. N. and E. Caulton. 2009. Pollen And Spores: Applications With Special Emphasis On Aerobiology And Allergy. Science Publishers. United States of America.
Behling H, dan Pillar VD. 2007. Late Quarternary Vegetation, Biodiversity and Fire Dynamics on The Southern Brazilian Highland and Their Implication for Conservation and Management of Modern Araucaria Forest and Grassland Ecosystems. Phil Trans $R$ Soc B 362: 243-251.

Ellison JC. 2008. Long-term Retrospection on Mangrove Development Using Sediment Cores and Pollen Analysis: A Review. Aqua. Bot. 89: 93-104.

Erdtman G. 1952. Morphology an Taxonomy Angiospermae: An Introduction to Palynology. Massachusetts, USA: The Botanica Company Wather.

Hesse,Halbritter, H., Zetter, R., Weber, M., Buchner, R., Frosch-Radivo, A., and Ulrich, S. 2009. Pollen Terminology. Springerverlag. Austria.

Huang TC. 1972. Pollen of Taiwan. Taipei, Taiwan: National Taiwan University, Botany Departemen Press.

Kapp, R. O. 1969. How To Know Pollen and Spores. WMc. Brown Company Publisher, Dubuque, Iowa, USA.

Lelono EB, Nugrahaningsih L, Tri Bambang SR, danWidiastuti R. 2001. Indikasi Perubahan Iklim pada Neogen Akhir di Pulau Jawa Berdasarkan Rekaman Palinologi. Lembaran Publikasi LEMIGAS Vol. 35 No.2.

Moore, P. D. and J. A. Webb. 1978. An Illustrated Guide To Pollen Analysis. The Ronald Press Company, New York.

Morley RJ. 2000. Origin and Evolution of Tropical Rain Forests. West Sussex, England: John Wiley and Sons Ltd.

Morley RJ. 1998. Palynological Evidence for Tertiary Plant Dispersals in The SE Asian Region in Relation to Plate Tectonics and Climate. Biogeography and Geological Evolution of SE Asia. Edited by Robert Hall and D Holloway. Leiden, The Netherlands: Backbuys Publishers. hlm 211-234.

Morley, R. J. 1990. Short Course Introduction To Palynology With Emphasis on Southeast Asia. Fakultas Biologi UNSOED. Purwokerto. 
Prebble, M., R. Sim, J. Finn and D. Fink. 2005. A Holocene Pollen and Diatom Record from Vanderlin Island, Gulf of Carpentaria, Lowland Tropical Australia. Quat. Res. 64: 357-371.

Rahardjo AT. 1999. Perubahan Iklim dan Batas Umur Pliosen-Plistosen Berdasarkan Analisis Foraminifera dan Palinologi di daerah Mojoroto Jawa Timur. Buletin Geologi ITB. Vol. 31 No.1. Bandung. hlm $1-13$.

Rahardjo AT, Yulianto E, danSetijadi R. 1998.Palinologi Formasi Nampol dan Hubungan Stratigrafinya dengan Formasi Punung di Daerah Punung, Kabupaten Pacitan. Buletin Geologi ITB, Vol. 29 No. 2. Bandung.

Setijadi, R., S. W. A. Suedy dan A. T. Rahardjo. 2005. Sejarah Flora Dan Vegetasi Formasi Kalibiuk Dan Kaliglagah Daerah Bumiayu Ditinjau Dari Bukti Palinologi. Prosiding Seminar Nasional MIPA Universitas Negeri Semarang- ISBN 979-9579-80-5.

Suedy SWA, dan Setijadi R. 2007. Fluktuasi Vegetasi Hutan Mangrove di Pantai Gandhong-Sayung Demak Berdasarkan Bukti Palinologinya. BIOSFER Vol 24 No 3: 57-61.
Suedy SWA, Soeprobowati TR, Rahardjo AT, dan Maryunani KA. 2006a. Keanekaragaman Flora Penyusun Hutan Mangrove Pantai Randusanga Brebes Ditinjau Dari Bukti Palinologinya. Di dalam: Prosiding Seminar Nasional UNSOED: Konservasi Biodiversitas Sebagai Penunjang Pembangunan Berkelanjutan; Purwokerto, Okt 2006. Purwokerto: Fakultas Biologi UNSOED. hlm 112-117.

Suedy SWA, Soeprobowati TR, Rahardjo AT, Maryunani KA, danSetijadi R. 2006b. Keanekaragaman Flora Hutan Mangrove di Pantai Kaliuntu Rembang Berdasarkan Bukti Palinologinya. BIODIVERSITAS Vol 7 No 4: 322-326.

Traverse A. 1988. Paleopalynology. Department of Geosciences, College of Earth and Mineral Science, The Pennsylvania State University. Boston.

Yulianto E, Tsuji H, Sukapti WS, and Tanaka N. 2005. A Holocene Pollen and Charcoal Record from a Tropical Lowland Swamp in Rawa Danau, West Java, Indonesia. Tropics Vol 14 (2). 